\title{
Metalaxyl-M, phosphorous acid and potassium silicate applied as soil drenches show different chestnut seedling performance and protection against Phytophthora root rot
}

\author{
Jorge Nuno Rosário • Valentim Coelho 1 - M. Ângelo Rodrigues $(1)$ \\ Soraia Raimundo - Sandra Afonso (1D - Margarida Arrobas (D) \\ M. Eugénia Gouveia
}

Accepted: 1 June 2021 / Published online: 8 June 2021

(C) Koninklijke Nederlandse Planteziektenkundige Vereniging 2021

\begin{abstract}
The application as soil drenches of three commercial products containing metalaxyl, phosphorous acid or potassium silicate, were studied as a means of controlling Phytophthora in chestnut (Castanea sativa Mill.) seedlings. In the metalaxyl treatment no plant deaths were recorded, whereas with the phosphorous acid and potassium silicate applications, and in the untreated control, the mortality rate was respectively 33.3, 44.4 and 77.8\%. The presence of Phytophthora was detected in plants and soils at the end of the experiment which means that the three products did not eliminate the pathogen, and that they only gave temporary protection to the plant. In the treatments receiving metalaxyl or phosphorous acid, the plants showed a sharp drop in growth compared to the surviving plants of the control. Soil analyses revealed a high increase in exchangeable acidity, a high reduction in $\mathrm{pH}$ and a high increase in Mn levels in the soils treated with the products containing metalaxyl or phosphorous acid. In these treatments, elemental tissue analysis and nutrient
\end{abstract}

J. N. Rosário • V. Coelho • M. Â. Rodrigues $(\bowtie)$.

S. Raimundo · S. Afonso • M. Arrobas - M. E. Gouveia

Centro de Investigação de Montanha (CIMO), Instituto

Politécnico de Bragança, Campus de Sta Apolónia,

5300-253 Bragança, Portugal

e-mail: angelor@ipb.pt

J. N. Rosário

e-mail: jorge.rosario@ipb.pt

V. Coelho recovery by plants revealed Mn levels far above the upper limit of the sufficiency range, with the toxicity of Mn being the suspected cause for the strong reduction in plant growth. These results indicate that when applying such products to the soil, their concentration and/or their ability to influence the soil $\mathrm{pH}$ should be evaluated and adequate measures of $\mathrm{pH}$ adjustment undertaken. In the case of phosphorous acid, its use can be replaced by phosphite salts. K-silicate did not show adverse effects on plant growth but provided less protection against Phytophthora than metalaxyl or phosphorous acid.

Keywords Castanea sativa . Ink disease, biostimulants . Phosphite Phosphonate - Molecular identification . Plant protection

e-mail: valentimcoelho@ipb.pt

S. Raimundo

e-mail: soraia-raimundo@live.com.pt

S. Afonso

e-mail: sandraafonso@ipb.pt

M. Arrobas

e-mail: marrobas@ipb.pt

M. E. Gouveia

e-mail: egouveia@ipb.pt 


\section{Introduction}

In Portugal, although the planted area of chestnut trees (Castanea sativa Mill.) has been increasing in recent years, the production of chestnut fruit has not followed a similar trend (FAOSTAT, 2020). A set of phytosanitary problems, of which ink disease is the most prevalent, has been affecting the species, leading to the death of mature trees so that producers are constantly replacing them with less productive young trees (Martins et al., 2007; Arrobas, Afonso, \& Rodrigues, 2018a; Rodrigues et al., 2019). However, this is not a local problem, with statistics from many other parts of the world, including European countries, showing the same pattern (FAOSTAT, 2020).

It was well-known from the beginning of the twentieth century that ink disease in chestnut is associated with species of the genus Phytophthora, namely $P$. cinnamomi Rands and P. cambivora (Petri) Buisman (Crandall et al., 1945; Petri, 1917). P. cambivora was recently re-described without nomenclatural act by Jung, Jung, Scanu, et al. (2017a) as P. xcambivora. Other species of Phytophthora, such as $P$. cactorum and $P$. plurivora (formely P. citricola) may also damage chestnut trees, although with a lesser degree of aggressiveness (Akilli et al., 2012; Biocca et al., 1993; Vettraino et al., 2005). In Portugal, P. cinnamomi is the most frequently isolated species from the chestnut ecosystem and is, therefore, considered the predominant species in the development of ink disease (CarneiroCarvalho et al., 2019; Fernandes, 1979; Gouveia, 2004). However, Jung, Jung, Cacciola, et al. (2017b) described a new cryptic species of Phytophthora (P. castanetorum) for Portugal, in The Algarve and in the Natural Park of Serra da Estrela that can cause severe ink disease symptoms and may occur simultaneously with the predominant abovementioned species. The pathogen infects the root system, causing blackening of the thinner roots due to the decomposition of the cortex, becoming moist and rotten. Thicker roots are also attacked, showing blackened spots, due to changes in the cortex and cambium. Symptoms of the disease on the aerial part of mature trees include chlorotic leaves reduced in size, thinning of the crown and immature husks which remain on the tree after leaf-fall (Vannini \& Vettraino, 2001). In young chestnuts, the entire plant acquires a yellowish appearance that quickly develops into necrosis and desiccation (Gouveia, 1993). As the result of the infection of the root system, a reduction in water and mineral uptake occurs, which causes a detrimental effect on growth and yield and ultimately leads to the death of whole trees (Erwin \& Ribeiro, 1996).

Metalaxyl, phosphites (salts of phosphorous acid) and phosphonates (phosphite esters) have been the most commonly used substances for the chemical control of Phytophthora, both in chestnut (Cohen \& Coffey, 1986; Guest et al., 1995; Stein \& Kirk, 2002) and in several other fruit tree species (Akinsanmi \& Drenth, 2013; Masikane et al., 2020; Nyoni et al., 2019; Türkölmez \& Derviş, 2017). Potassium silicate has become increasingly important in agriculture as a biostimulant capable of helping plants to cope with abiotic and biotic stresses (Carneiro-Carvalho et al., 2020; Savvas \& Ntatsi, 2015) and is now recognized as a useful tool to be used against Phytophthora (Bekker et al., 2014).

Metalaxyl has long been considered the most effective and versatile fungicide for the control of diseases caused by Phytophthora (Schwinn et al., 1977; Urech et al., 1977). It is a systemic fungicide, with apoplastic translocation, interfering with the RNA synthesis of Phytophthora species. It is usually applied preventively although it can also be applied as a therapeutic fungicide on plants which are already infected (Davidse, 1987; Erwin \& Ribeiro, 1996). In crops in which Phytophthora species attack the shoots, it is usually applied as a foliar spray (Liljeroth et al., 2016; Lu et al., 2018). In tree species in which oomycetes of the genus Phytophthora attack the roots, treatments such as soil drenches are also common (Akinsanmi \& Drenth, 2013; Türkölmez and Derviş 2017).

Phosphite is translocated in both upward and downward directions in xylem and phloem (Erwin \& Ribeiro, 1996) which allows it to be applied as foliar and trunk sprays, trunk injections or as soil drenches (Akinsanmi \& Drenth, 2013; Coelho, 2009; Masikane et al., 2020). Phosphite has good properties as an inhibitor of plant pathogens (Fenn \& Coffey, 1984; Gomez-Merino \& Trejo-Telle, 2015), and has given good results in Phytophthora control in tree species in which the oomycete infects the roots (Akinsanmi \& Drenth, 2013; González et al., 2020; Nyoni et al., 2019). Phosphite can control diseases caused by $P$. cinnamomi, directly through the inhibition of pathogen growth, or indirectly through enhancement of plant defences (Hardham \& Blakman, 2018).

However, neither metalaxyl nor phosphites can overcome effectively the problem of ink disease in the longterm. In previous studies it has been reported that the 
continued use of metalaxyl or phosphites can lead to decreased efficacy, or the development of resistance by the pathogen (Dobrowolski et al., 2008; Hu et al., 2010). Researchers are currently therefore focused on developing alternative tools to help farmers to manage this important plant disease (Ramírez-Gil and MoralesOsorio (2020).

Potassium silicate appeared on the market as a slowrelease fertilizer in 1978 (Ma \& Takahashi, 2002). Although the effectiveness of silicon ( $\mathrm{Si}$ ) in the control of plant diseases, as well as its mode of action, are not very well understood. Carneiro-Carvalho et al. (2017) reported that Si appears to be a possible inducer of resistance to $P$. cinnamomi in chestnut trees. Previous in vitro studies, performed by Kaiser et al. (2005), also found that $5 \mathrm{ml}$ soluble Si per litre of agar inhibited the growth of $P$. cinnamomi by $100 \%$. Thus, it seems that potassium silicate can be one more tool to manage ink disease. It is included in the group of biostimulants, in accordance with the European Union Regulation (EU) 2019/1009.

In this study, two commercial products containing active ingredients with a recognized high potential to control or reduce the incidence of ink disease, mainly metalaxyl-M and phosphorous acid, were compared with potassium silicate, a plant biostimulant of some interest but little studied in the control of Phytophthora in chestnut. All products were applied as soil drenches to young nursery plants. The experiment also included an untreated control. In monitoring the effects of the treatments, the growth of the seedlings, their survival rates, the elemental composition of plant tissues (roots, stems and leaves) and soil properties were assessed, and Phytophthora was detected and identified from soil samples.

\section{Materials and methods}

\section{Greenhouse assay}

Planting stock was obtained by stratification of seeds from certified sites of $C$. sativa in moist sand during winter to allow a better and concentrated germination. In late winter, the sprouted chestnuts were planted in pots of $4 \mathrm{~L}$ in volume. The growing medium was soil heavily infected (in the initial bait test of the soil almost all baits were infected with Phytophthora), collected from beneath the canopy of chestnut trees with severe ink disease symptoms, mixed with perlite in a ratio of $3: 1(\mathrm{v} /$ v).

The experiment was arranged as a completely randomized design with four treatments and nine replications (nine plants per treatment). The treatments consisted of three commercial products, containing metalaxyl-M, phosphorous acid or potassium silicate (K-silicate), and an untreated control. The composition of the commercial product containing metalaxyl-M was $40 \%$ folpet $(w / w)$ and $5 \%$ metalaxyl-M (w/w). It was used at a rate of $2 \mathrm{~g} \mathrm{~L}^{-1}$. The composition of the product containing phosphorous acid $\left(\mathrm{H}_{3} \mathrm{O}_{3}\right)$ (the conjugate acid of the phosphite anion, $\mathrm{H}_{2} \mathrm{PO}_{3}{ }^{-}$) was $3.0 \% \mathrm{~N}, 35 \%$ $\mathrm{H}_{3} \mathrm{PO}_{3}, 0.2 \% \mathrm{Fe}, 2.8 \% \mathrm{Mn}$ and $1.0 \% \mathrm{Zn}$ (it was prepared from algae extracts, micronutrients, $\mathrm{H}_{3} \mathrm{PO}_{3}$ and coadjutants) and was applied at the concentration of $4 \mathrm{ml} \mathrm{L}^{-1}$. K-silicate was composed of 25 to $27 \% \mathrm{SiO}_{2}$ and 12 to $13 \% \mathrm{~K}_{2} \mathrm{O}$ and was used at the same concentration as phosphorous acid.

The products were applied twice, the first time on May 7th, 2018, with the second application being performed 3 weeks later. All the solutions containing the active ingredients were prepared, and $500 \mathrm{ml}$ poured directly onto the soil of the pots around each plant. The control treatment received $500 \mathrm{ml}$ of water.

After the installation of the experiment, the pots were weeded as required. $500 \mathrm{ml}$ water was used for each irrigation. The number of weekly watering's depended on the environmental conditions in the greenhouse. The irrigation frequency was adjusted in order to avoid exceeding the field capacity and anaerobic conditions of the growing medium.

Plant performance evaluation and tissue and soil sample collection

Plant death was recorded throughout the experimental period. At the end of the experiment (October 29th, 2018), several morphological traits, such as plant height, stem diameter and the length and width of the leaves were measured. Thereafter, the live plants were uprooted and separated into roots, stems and leaves. The roots were washed with a gentle flow of water. From each treatment, samples of blackening and rotten roots were taken for detection of Phytophthora. All plant tissues were oven-dried at $70{ }^{\circ} \mathrm{C}$, weighed and ground. Soil samples were also taken after the soil in each pot was properly mixed. Two subsamples were 
prepared, the first for the detection of Phytophthora and the other for the determination of the effect of the treatments on soil properties. For detection of Phytophthora, the soil samples did not receive additional pre-treatments; they were used fresh as collected from the pots. For the determination of soil properties, the soil was oven-dried at $40{ }^{\circ} \mathrm{C}$.

Detection and identification of Phytophthora species

For Phytophthora detection in the soil samples, the method of biological trap with chestnut leaf discs, as proposed by Gouveia et al. (2009), was used. From each sample, $20 \mathrm{ml}$ of soil was placed on a $120 \mathrm{~mm}$ diameter Petri dish. In each dish, $8 \mathrm{ml}$ of distilled water was added along with twenty disks of chestnut leaves, $0.5 \mathrm{~cm}$ in diameter. The dishes were placed at room temperature and, after 24, 48 and $72 \mathrm{~h}$, three discs of leaves from each dish were removed and placed in PARPH selective culture medium (Pimaricin, $5 \mathrm{mg} \mathrm{L}^{-1}$; Ampicillin, $250 \mathrm{mg} \mathrm{L}{ }^{-1}$; Rifanpicin, $10 \mathrm{mg} \mathrm{L}^{-1}$; Hymexazole, $25 \mathrm{mg} \mathrm{L}^{-1}$ ) for Phytophthora growth. The same PARPH selective culture medium was used at the end of the experiment for detection of Phytophthora from roots with symptoms of blackening and moist decay. The presence of Phytophthora was confirmed by microscopic observation at the hyphae level. After mycelial growth, the isolates were cultured on PDA medium (Potato Dextrose Agar, Difco $39 \mathrm{~g} \mathrm{~L}^{-1}$ ) for later molecular identification of the species.

The identification of Phytophthora species was based on morphological characteristics and molecular methods by amplification and sequencing of the ITS (ITS1, 5.8S, ITS2) in the ribosomal DNA (rDNA) region using the ITS1 and ITS6 universal primers (White et al., 1990) and comparing with sequences published in the GenBank databases, BLAST (https://blast.ncbi.nlm. nih.gov/). DNA extraction from Phytophthora isolates was performed using the REDExtract-N-Amp ${ }^{\mathrm{TM}}$ Plant PCR Kit (Sigma-Aldrich), and amplified region sequencing was performed by Stabvida Laboratories (Caparica, Portugal). Each species was classified taxonomically according to the MycoBank Database (www.micobank.org).

Soil and plant tissue analyses

Soil samples were submitted to the following analytical determinations: 1) $\mathrm{pH}\left(\mathrm{H}_{2} \mathrm{O}\right.$ and $\left.\mathrm{KCl}\right)$ (by potentiometry); 2) organic C (Walkley-Black method); 3 ) cation exchange capacity (ammonium acetate, $\mathrm{pH}$ 7.0); 4) extractable $\mathrm{P}$ and $\mathrm{K}$ (ammonium lactate solution at $\mathrm{pH} 3.7$ ); 5) extractable $\mathrm{Fe}, \mathrm{Mn}, \mathrm{Zn}$ and $\mathrm{Cu}$ (ammonium acetate and EDTA, determined by atomic absorption spectrometry); and 6) extractable B (Hot water, and azomethine-H). Methods 1-3, 5 and 6 were fully described by Van Reeuwijk (2002) and method 4 by Balbino (1968).

Elemental analyses of all the tissues (leaves, stems and roots) were performed by Kjeldahl $(\mathrm{N})$, colorimetry (B and $\mathrm{P}$ ), and atomic absorption spectrophotometry (K, $\mathrm{Ca}, \mathrm{Mg}, \mathrm{Fe}, \mathrm{Mn}, \mathrm{Cu}, \mathrm{Zn}$ ) methods (Temminghoff \& Houba, 2004) after tissue samples were digested with nitric acid in a microwave.

\section{Data analysis}

Data was firstly tested for normality and homogeneity of variances using the Shapiro-Wilk test and Bartlett's test, respectively. The comparison of the effect of the treatments was provided by one-way ANOVA. When significant differences were found $(\alpha<0.05)$, the means were separated by the multiple range Tukey HSD test $(\alpha=0.05)$.

\section{Results}

Plant growth

All the chemical treatments reduced the rate of plant mortality in comparison to the control. In the metalaxyl treatment all the plants survived, whereas in the control treatment only $22.2 \%$ survived (Table 1 ). However, at the end of the experiment, surviving plants of the control treatment showed an increased average height, stem diameter, leaf number and a higher number of fully developed leaves, although significant differences between treatments $(P<0.05)$ were only found in stem diameter and leaf number.

The surviving plants in the control treatment showed significantly higher dry matter yield in comparison to the plants of the phosphorus acid and metalaxyl treatments (Fig. 1). This extended to the dry biomass of roots, stems and leaves. The plants of the K-silicate treatment showed total dry matter yield not significantly different from that of the control treatment. 
Detection and identification of Phytophthora

The bait method for soil detection of Phytophthora with chestnut leaf discs revealed the presence of Phytophthora hyphae in the control treatment after $24 \mathrm{~h}$ of contact between the soil and the chestnut leaves (Table 2). In the treated plants, the presence of hyphae of the oomycete only occurred after $48 \mathrm{~h}$ of incubation. At 48 and $72 \mathrm{~h}$ of incubation all the treatments including metalaxyl revealed the presence of Phytophthora hyphae in the baits.

From the isolates obtained from the discs of chestnut leaves infected with Phytophthora, 11 isolates were selected for molecular identification of the species. The sequences were compared with other sequences published in the GenBank databases using Blast and Blastn (https://blast.ncbi.nlm.nih.gov/). The sequence identities of 10 isolates of Phytophthora were above a 99\% cut-off to the ex-type isolate (NCBI Accession number: FJ801806) used to compare sequences obtained in this study. For one isolate obtained in the control (pot 2) the sequence identity was $98.00 \%$. However, as in the Blast, the obtained results showed that all 100 sequences selected belonged to the species $P$. cinnamomi, so we consider that by the Blast criteria this isolate is P. cinnamomi (Table 3 ).

P. cinnamomi was also detected from root and collar rot lesion samples in each treatment including the metalaxyl-M treatment. After molecular identification, sequences were deposited in the NCBI data base with the accession number: MW769784, MW769927, MN960436, MW772238, MW772384, MW769778 and MW772365. Sequence based identification of Phytophthora obtained from the root tissue of plants revealed the same percentage of base identity obtained from the soil, including pot 2 of the control, with values close to $98 \%$.

Tissue elemental composition and soil properties

Root $\mathrm{N}$ concentrations varied significantly between treatments (Table 4). The plants of the phosphorous acid treatment showed significantly higher values than those of the other treatments. The plants of the metalaxyl treatment, in turn, showed significantly higher leaf $\mathrm{N}$ concentrations than that of the control and K-silicate treatments. For concentrations of $\mathrm{P}$ in the roots, the values of the plants treated with phosphorous acid stand out with values significantly higher than that of the other treatments. Root $\mathrm{K}$ concentrations were significantly higher in the plants of the $\mathrm{K}$-silicate in comparison to that of the other treatments. Ca concentrations in the roots did not vary significantly between treatments. The higher values of $\mathrm{Mg}$ in the roots were recorded in the phosphorous acid and metalaxyl treatments, whereas the higher $\mathrm{B}$ and $\mathrm{Zn}$ values were found in the phosphorous acid, and the higher Mn values in the phosphorous acid followed by metalaxyl treatments.

Leaf $\mathrm{N}$ concentration was significantly higher in the metalaxyl and phosphorous acid treatments than in the $\mathrm{K}$-silicate and control treatments (Table 5). Leaf $\mathrm{P}$ levels, in turn, were significantly higher in the phosphorus acid in comparison to the other treatments. Leaf $\mathrm{K}$ levels were significantly higher in the K-silicate treatment in comparison to the others. The values of $\mathrm{Ca}$ and $\mathrm{Mg}$ in the leaves reached the highest and lowest values, respectively, in the metalaxyl and K-silicate treatments. $B$ values also registered significant differences between treatments, with the higher values to be found in the phosphorous acid and metalaxyl treatments. In the cases of $\mathrm{Cu}$ and $\mathrm{Fe}$, the higher values were recorded respectively in the metalaxyl treatments and the control. The values of $\mathrm{Zn}$ and $\mathrm{Mn}$ were markedly higher in the phosphorus acid treatment.

The concentrations of nutrients in the stems followed the general pattern observed in the leaves (data not shown), although they were lower in relative terms for all nutrients, showing a tissue with greater lignification and $\mathrm{C}$ concentration.

Nutrient recovery is the product of dry matter yield and tissue nutrient concentration. $\mathrm{N}$ recovery in total plant biomass did not vary significantly between treatments. P recovery was significantly higher in the phosphorus acid in comparison to metalaxyl treatment (Table 6). K recovery was significant and particularly higher in the K-silicate in comparison to the other treatments. The recovery of $\mathrm{Ca}, \mathrm{Mg}$ and $\mathrm{B}$ in plant tissues did not vary significantly between treatments. The higher recovery values of $\mathrm{Cu}$ and $\mathrm{Fe}$ were found in the $\mathrm{K}$-silicate treatment, whereas the higher values of $\mathrm{Zn}$ and $\mathrm{Mn}$ were observed in the phosphorous acid treatment.

Soil organic $\mathrm{C}$ did not change significantly with fungicidal treatments, varying between 23.8 to $27.8 \mathrm{~g} \mathrm{~kg}^{-1}$ (Table 7). However, the treatments influenced soil $\mathrm{pH}$ greatly. The values decreased significantly in the order of K-silicate (6.3), control (5.6), metalaxyl (4.9) and phosphorous acid (4.4). Extractable 
Table 1 Morphological traits of surviving plants (average \pm standard deviation) at the end of the experimental period

\begin{tabular}{llllll}
\hline & Live plants $(\%)$ & Plant height $(\mathrm{cm})$ & Stem diameter $(\mathrm{cm})$ & Leaf number & Fully developed leaves $(\%)$ \\
\hline Control & 22.2 & $74.5 \pm 51.62 \mathrm{a}$ & $1.3 \pm 0.14 \mathrm{a}$ & $21.0 \pm 6.00 \mathrm{a}$ & $72.2 \pm 5.56 \mathrm{a}$ \\
Phosphorous acid & 66.7 & $25.9 \pm 15.05 \mathrm{a}$ & $0.6 \pm 0.23 \mathrm{~b}$ & $16.2 \pm 4.07 \mathrm{~b}$ & $40.5 \pm 15.78 \mathrm{a}$ \\
Metalaxyl & 100 & $24.2 \pm 20.00 \mathrm{a}$ & $0.7 \pm 0.19 \mathrm{~b}$ & $12.8 \pm 3.96 \mathrm{~b}$ & $41.0 \pm 14.55 \mathrm{a}$ \\
K-silicate & 55.6 & $34.0 \pm 27.38 \mathrm{a}$ & $0.9 \pm 0.34 \mathrm{ab}$ & $17.6 \pm 5.13 \mathrm{ab}$ & $51.7 \pm 15.06 \mathrm{a}$ \\
Prob. & & 0.0807 & 0.0093 & 0.1052 & 0.0587 \\
\hline
\end{tabular}

Means followed by the same letter are not significantly different by Tukey HSD test $(\alpha=0.05)$

P decreased significantly from the phosphorus acid (174.1 $\mathrm{mg} \mathrm{kg}^{-1}$ ) to the control treatment $\left(105.7 \mathrm{mg} \mathrm{kg}^{-1}\right)$. Extractable and exchangeable $\mathrm{K}$ were approximately six times higher in the K-silicate than in the other treatments. Exchangeable $\mathrm{Ca}$ and $\mathrm{Mg}$ were also the highest in the K-silicate treatment. Exchangeable acidity was higher in the soil of the pots receiving phosphorous acid, which were also those showing the lower $\mathrm{pH}$ values. Extractable $\mathrm{Zn}$ was particularly high in the phosphorous acid pots, whose average value was $21.4 \mathrm{mg} \mathrm{kg}^{-1}$ whereas, in the other pots, $\mathrm{Zn}$ values varied from 1.3 to $1.6 \mathrm{mg} \mathrm{kg}^{-1}$. Phosphorous acid and K-silicate treatments showed significantly higher $\mathrm{Mn}$ levels than the metalaxyl and control treatments.

\section{Discussion}

Metalaxyl provided greater protection for plants against chestnut ink disease, with no deaths recorded during the experimental period. Phosphorous acid (33\% mortality) and K-silicate (44\% mortality) provided a higher degree of protection than the control treatment (78\% mortality), but much lower than metalaxyl. None of the substances eliminated Phytophthora since the oomycete was found in the soil in all treatments at the end of the experiment. However, no symptoms of the disease were observed in the plants treated with metalaxyl. Metalaxyl has been considered one of the most effective substances in controlling Phytophthora, even in already infected plants (Akinsanmi \& Drenth, 2013; Davidse, 1987; Erwin \& Ribeiro, 1996; Schwinn et al., 1977), although its effectiveness depends on variables associated with the agrosystem (Guest \& Bompeix, 1990).

The mortality of $33 \%$ of the plants in the phosphorous acid pots may have been the result of its application to the soil, which according to some authors may not have been the most effective method of protecting the plant roots. Phosphite (hydrogen phosphite, $\mathrm{H}_{2} \mathrm{PO}_{3}{ }^{-}$), resulting from the deprotonation of phosphorous acid, is fully systemic in plants and can be translocated in both the xylem and the phloem (Guest \& Grant, 1991;

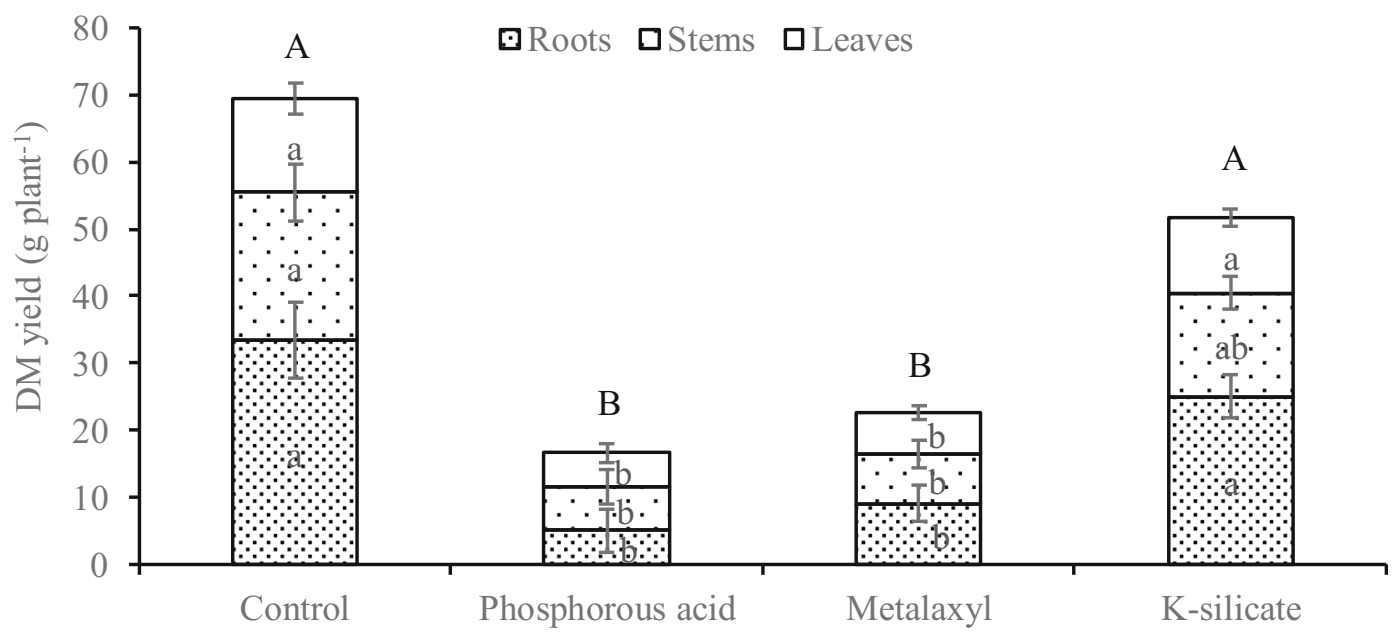

Fig. 1 Dry matter yield of surviving plants. To each plant part or total, means followed by the same letter (lowercase and uppercase, respectively) were not significantly different by Tukey HSD test $(\alpha=0.05)$; vertical bars are the standard errors 
Table 2 Phytophthora detection in the different fungicidal treatments and trapping times

\begin{tabular}{lccc}
\hline & $24 \mathrm{~h}$ & $48 \mathrm{~h}$ & $72 \mathrm{~h}$ \\
\hline Control & + & + & + \\
Phosphorous acid & - & + & + \\
Metalaxyl & - & + & + \\
K-silicate & - & + & + \\
\hline
\end{tabular}

+ Phytophthora detection in at least one disc of chestnut leaf; - no detection of Phytophthora

McDonald et al., 2001). Its great mobility in the plant allows it to be applied in different ways, including soil drenching, trunk injection or as a foliar spray (Akinsanmi \& Drenth, 2013; Cohen \& Coffey, 1986; Crane \& Shearer, 2014; Masikane et al., 2020). Studies on apple trees performed by Nyoni et al. (2019) have shown that foliar applications of phosphite are more effective in providing phosphite to the roots than a soil drench. Darvas et al. (1984), for instance, reported that the most effective application method for phosphonates, in avocado, was trunk injection. Guest and Grant (1991) report that pathogen suppression occurs at higher phosphite concentrations (direct inhibition), while host plant resistance induction is associated with low phosphite concentrations (indirect inhibition). In addition, phosphorus acid or phosphite applied to the soil may lose efficiency in the long-term, since it can be converted to phosphate by soil microorganisms (du Jardin, 2012; McDonald et al., 2001). According to Gomez-Merino and Trejo-Telle (2015) this can occur within 3-

Table 3 Species identification and percentage of nucleotide identity of each identified species

\begin{tabular}{lll}
\hline Origen of detection & Species & Identity (\%) \\
\hline Control, pot 1 & Phytophthora cinnamomi 99 \\
Control, pot 2 & Phytophthora cinnamomi 98 \\
Control, pot 6 & Phytophthora cinnamomi 99 \\
Phosphorous acid, pot 2 & Phytophthora cinnamomi 99 \\
Phosphorous acid, pot 9 & Phytophthora cinnamomi 100 \\
Metalaxyl, pot 6 & Phytophthora cinnamomi 100 \\
Metalaxyl, pot 9 & Phytophthora cinnamomi 99 \\
K-silicate, pot 1 & Phytophthora cinnamomi 99 \\
K-silicate, pot 2 & Phytophthora cinnamomi 99 \\
K-silicate, pot 6 & Phytophthora cinnamomi 99 \\
K-silicate, pot 9 & Phytophthora cinnamomi 99 \\
\hline
\end{tabular}

4 months, a shorter period than the duration of this experiment.

The effect of $\mathrm{Si}$ in the control of plant diseases, its mode of action and its function in various pathosystems, is not yet fully understood. There is a hypothesis of a possible physical barrier formation, which is based on the accumulation of Si in plants, mainly in the cell wall. In its upward movement (apoplast movement), from roots to leaves, polymerization of Si occurs in the extracellular spaces, accumulating in the walls of the epidermal cells of the leaves and xylem vessels (Kim et al., 2002; Savvas \& Ntatsi, 2015). Although in vitro studies carried out by Kaiser et al. (2005) reported $100 \%$ growth inhibition of $P$. cinnamomi, in this study the application to the soil of potassium silicate was not as effective, allowing a mortality of $44 \%$ at the end of the experiment.

Metalaxyl and, to a lesser extent, phosphorous acid treatments, protected the plants from death, but the surviving plants showed very poor growth performance compared to the surviving plants of the control treatment. Regarding metalaxyl, Sousa et al. (2017) reported a decrease in RuBisCO activity in Solanun nigrum, which resulted in photosynthesis inhibition and an abrupt decrease in plant growth. However, we think this was not the case in this experiment. A more consistent thesis will be provided with the discussion of the results of the concentration and recovery of nutrients in plant tissues and soil properties. Phosphite, in turn, can cause phytotoxicity in a wide range of species when present in plant tissues at high concentrations (Akinsanmi \& Drenth, 2013; Barrett et al., 2004; Pilbeam et al., 2000). In addition, phosphite is not metabolized in cells, but recent investigations into biochemical and genetical mechanisms of phosphite action indicate that phosphite behaves as a phosphate analog, mimicking phosphate in plant cells but without making its $\mathrm{P}$ available for cell metabolism, inducing P deficiency (du Jardin, 2012). However, this second hypothesis does not seem to be a relevant cause for the reduction of dry matter yield in plants treated with phosphorous acid, considering the results of the tissue analysis that will be discussed later.

Ink disease of chestnut is endemic in Europe with cyclical resurgences, causing high tree mortality (Vannini \& Vettraino, 2001). The disease has similar effects in Portugal. In the Trás-os-Montes, the biggest chestnut producing region of the country, $15 \%$ of the trees are affected by the disease (Gouveia, 2004). The detection technique (baiting trap) confirmed the presence 
Table 4 Root nutrient concentration (average \pm standard deviation) in the different treatments

\begin{tabular}{|c|c|c|c|c|}
\hline Nutrient & Control & Phosphorous acid & Metalaxyl & $\mathrm{K}$-silicate \\
\hline Nitrogen $\left(\mathrm{g} \mathrm{kg}^{-1}\right)$ & $6.1 \pm 1.08 \mathrm{c}$ & $22.9 \pm 1.32 \mathrm{a}$ & $14.4 \pm 0.65 \mathrm{~b}$ & $5.8 \pm 0.36 \mathrm{c}$ \\
\hline Phosphorus $\left(\mathrm{g} \mathrm{kg}^{-1}\right)$ & $0.8 \pm 0.05 \mathrm{~b}$ & $3.9 \pm 0.33 \mathrm{a}$ & $1.1 \pm 0.15 \mathrm{~b}$ & $1.0 \pm 0.13 \mathrm{~b}$ \\
\hline Potassium $\left(\mathrm{g} \mathrm{kg}^{-1}\right)$ & $3.5 \pm 0.28 \mathrm{~b}$ & $5.1 \pm 0.52 b$ & $5.1 \pm 0.20 \mathrm{~b}$ & $7.3 \pm 1.14 \mathrm{a}$ \\
\hline Calcium $\left(\mathrm{g} \mathrm{kg}^{-1}\right)$ & $2.5 \pm 0.33 \mathrm{a}$ & $2.5 \pm 0.45 \mathrm{a}$ & $3.0 \pm 0.21 \mathrm{a}$ & $2.6 \pm 0.13 \mathrm{a}$ \\
\hline Magnesium $\left(\mathrm{g} \mathrm{kg}^{-1}\right)$ & $1.6 \pm 0.41 \mathrm{ab}$ & $2.1 \pm 0.17 \mathrm{a}$ & $2.1 \pm 0.07 \mathrm{a}$ & $1.4 \pm 0.12 \mathrm{~b}$ \\
\hline Boron $\left(\mathrm{mg} \mathrm{kg}^{-1}\right)$ & $19.6 \pm 3.37 b$ & $29.6 \pm 0.34 \mathrm{a}$ & $25.5 \pm 2.31 \mathrm{ab}$ & $23.2 \pm 2.41 \mathrm{~b}$ \\
\hline Copper (mg kg $\left.{ }^{-1}\right)$ & $9.4 \pm 1.62 \mathrm{a}$ & $11.3 \pm 1.26 \mathrm{a}$ & $10.8 \pm 1.68 \mathrm{a}$ & $11.1 \pm 1.68 \mathrm{a}$ \\
\hline Iron $\left(\mathrm{mg} \mathrm{kg}^{-1}\right)$ & $2141.3 \pm 153.0 \mathrm{a}$ & $2195.4 \pm 205.8 \mathrm{a}$ & $1909.7 \pm 153.8 \mathrm{a}$ & $1875.4 \pm 100.9 \mathrm{a}$ \\
\hline Zinc $\left(\mathrm{mg} \mathrm{kg}^{-1}\right)$ & $23.3 \pm 2.1 \mathrm{c}$ & $250.3 \pm 7.4 \mathrm{a}$ & $37.5 \pm 3.3 \mathrm{~b}$ & $27.6 \pm 2.4 \mathrm{bc}$ \\
\hline Manganese $\left(\mathrm{mg} \mathrm{kg}^{-1}\right)$ & $241.9 \pm 19.7 \mathrm{c}$ & $1233.9 \pm 73.9 \mathrm{a}$ & $706.6 \pm 66.0 \mathrm{~b}$ & $261.4 \pm 18.4 \mathrm{c}$ \\
\hline
\end{tabular}

Means followed by the same letter are not significantly different by Tukey HSD test $(\alpha=0.05)$

of Phytophthora in all soil samples analysed which included all treatments. This biodetection method has proven to be effective for the detection of Phytophthora from soil samples (Gouveia et al., 2009). The technique allowed the identification of $P$. cinnnamomi as the dominant Phytophthora species present in the soil at the end of the experiment. In Portugal, three species of Phytophthora have been associated with the chestnut tree (P. cinnamomi, P. cambivora and the cryptic species $P$. castanetorum). However, $P$. cinnamomi is the species most commonly detected from soil samples and plant tissue from chestnut stands and it is considered the predominant pathogen in the development of ink disease (Fernandes, 1979; Gouveia, 2004), which is in agreement with the results of this study. Similarity of $98 \%$ with $P$. cinnamomi was obtained on root tissues from pot 2 (soil without any treatment) and also on the same pot at the end of the experiment when identification of Phytophthora species was based on ITS sequences. However, percentages up to $99 \%$ similarity or even $100 \%$ were obtained in all other treatments or field control replications. Applying the "Species Hypotheses" based on interspecific similarities of between 97 and 99\% (Hibbett et al., 2016) for Sequence Based Identification, all isolates were considered to be P.cinnamomi in the context of this work. Nevertheless, consistent differences in similarity among Phytophthora isolates justifies further studies to characterise Phytophthora species populations associated with chestnut ink disease in the Trás-osMontes region. Morphological and physiological characteristics used in combination with DNA sequence data from the ITS, part of the nuclear heat shock protein 90 (HSP90), and $\beta$ tubulin (Btub), mitochondrial cox 1 and NADH genes can be considered, as used to characterize

Table 5 Leaf nutrient concentration (average \pm standard deviation) in the different treatments

\begin{tabular}{|c|c|c|c|c|}
\hline Nutrient & Control & Phosphorous acid & Metalaxyl & K-silicate \\
\hline Nitrogen $\left(\mathrm{g} \mathrm{kg}^{-1}\right)$ & $13.7 \pm 1.53 \mathrm{~b}$ & $19.2 \pm 0.45 \mathrm{a}$ & $20.7 \pm 1.60 \mathrm{a}$ & $13.6 \pm 1.31 \mathrm{~b}$ \\
\hline Phosphorus $\left(\mathrm{g} \mathrm{kg}^{-1}\right)$ & $1.1 \pm 0.14 \mathrm{~b}$ & $6.3 \pm 1.07 \mathrm{a}$ & $1.4 \pm 0.04 \mathrm{~b}$ & $1.8 \pm 0.18 \mathrm{~b}$ \\
\hline Potassium $\left(\mathrm{g} \mathrm{kg}^{-1}\right)$ & $6.4 \pm 0.59 \mathrm{~b}$ & $6.5 \pm 0.58 \mathrm{~b}$ & $5.8 \pm 0.09 \mathrm{~b}$ & $31.8 \pm 1.23 \mathrm{a}$ \\
\hline Calcium $\left(\mathrm{g} \mathrm{kg}^{-1}\right)$ & $4.9 \pm 0.93 \mathrm{~b}$ & $7.1 \pm 0.64 \mathrm{ab}$ & $8.2 \pm 1.65 \mathrm{a}$ & $2.0 \pm 0.06 \mathrm{c}$ \\
\hline Magnesium $\left(\mathrm{g} \mathrm{kg}^{-1}\right)$ & $3.7 \pm 0.44 \mathrm{~b}$ & $4.9 \pm 0.47 \mathrm{ab}$ & $6.1 \pm 0.83 \mathrm{a}$ & $1.4 \pm 0.40 \mathrm{c}$ \\
\hline Boron $\left(\mathrm{mg} \mathrm{kg}^{-1}\right)$ & $64.8 \pm 12.20 \mathrm{~b}$ & $186.1 \pm 12.43 \mathrm{a}$ & $179.4 \pm 19.80 \mathrm{a}$ & $72.6 \pm 7.40 \mathrm{~b}$ \\
\hline Copper $\left(\mathrm{mg} \mathrm{kg}^{-1}\right)$ & $8.1 \pm 0.96 \mathrm{ab}$ & $9.4 \pm 1.23 \mathrm{ab}$ & $10.5 \pm 1.07 \mathrm{a}$ & $7.8 \pm 0.52 b$ \\
\hline Iron $\left(\mathrm{mg} \mathrm{kg}^{-1}\right)$ & $232.2 \pm 23.13 \mathrm{a}$ & $84.7 \pm 7.59 \mathrm{~b}$ & $92.4 \pm 5.78 \mathrm{~b}$ & $103.5 \pm 12.04 \mathrm{~b}$ \\
\hline Zinc $\left(\mathrm{mg} \mathrm{kg}^{-1}\right)$ & $36.4 \pm 7.11 \mathrm{~b}$ & $380.8 \pm 10.16 \mathrm{a}$ & $40.4 \pm 7.08 \mathrm{~b}$ & $24.1 \pm 6.02 \mathrm{~b}$ \\
\hline Manganese $\left(\mathrm{mg} \mathrm{kg}^{-1}\right)$ & $1806.3 \pm 334.1 \mathrm{c}$ & $15,343.2 \pm 1883.5 \mathrm{a}$ & $8754.9 \pm 782.4 \mathrm{~b}$ & $1115.8 \pm 310.3 \mathrm{c}$ \\
\hline
\end{tabular}

Means followed by the same letter are not significantly different by Tukey HSD test $(\alpha=0.05)$ 
Table 6 Nutrient recovery in total plant dry biomass (average \pm standard deviation) in the different treatments

\begin{tabular}{|c|c|c|c|c|}
\hline Nutrient & Control & Phosphorous acid & Metalaxyl & $\mathrm{K}$-silicate \\
\hline Nitrogen $\left(\mathrm{g} \mathrm{kg}^{-1}\right)$ & $258.4 \pm 33.34 \mathrm{a}$ & $241.6 \pm 22.76 \mathrm{a}$ & $318.7 \pm 29.65 \mathrm{a}$ & $271.5 \pm 19.04 \mathrm{a}$ \\
\hline Phosphorus $\left(\mathrm{g} \mathrm{kg}^{-1}\right)$ & $27.5 \pm 2.43 \mathrm{ab}$ & $53.1 \pm 6.12 \mathrm{a}$ & $24.0 \pm 1.97 \mathrm{~b}$ & $43.9 \pm 5.21 \mathrm{ab}$ \\
\hline Potassium $\left(\mathrm{g} \mathrm{kg}^{-1}\right)$ & $146.0 \pm 12.82 \mathrm{~b}$ & $61.4 \pm 7.93 b$ & $100.5 \pm 9.95 b$ & $550.3 \pm 62.34 \mathrm{a}$ \\
\hline Calcium $\left(\mathrm{g} \mathrm{kg}^{-1}\right)$ & $113.1 \pm 9.78 \mathrm{a}$ & $60.5 \pm 7.09 \mathrm{a}$ & $105.0 \pm 11.46 \mathrm{a}$ & $88.9 \pm 7.90 \mathrm{a}$ \\
\hline Magnesium $\left(\mathrm{g} \mathrm{kg}^{-1}\right)$ & $72.5 \pm 8.67 \mathrm{a}$ & $41.8 \pm 5.23 \mathrm{a}$ & $72.0 \pm 8.32 \mathrm{a}$ & $52.8 \pm 5.12 \mathrm{a}$ \\
\hline Boron $\left(\mathrm{mg} \mathrm{kg}^{-1}\right)$ & $1.1 \pm 0.21 \mathrm{a}$ & $1.1 \pm 0.09 \mathrm{a}$ & $1.6 \pm 0.17 \mathrm{a}$ & $1.4 \pm 0.16 \mathrm{a}$ \\
\hline Copper (mg kg $\left.{ }^{-1}\right)$ & $0.3 \pm 0.29 \mathrm{ab}$ & $0.1 \pm 0.01 \mathrm{~b}$ & $0.2 \pm 0.01 \mathrm{ab}$ & $0.3 \pm 0.04 \mathrm{a}$ \\
\hline Iron $\left(\mathrm{mg} \mathrm{kg}^{-1}\right)$ & $31.0 \pm 3.32 \mathrm{a}$ & $10.0 \pm 2.02 \mathrm{~b}$ & $18.3 \pm 1.89 \mathrm{ab}$ & $36.2 \pm 2.98 \mathrm{a}$ \\
\hline Zinc $\left(\mathrm{mg} \mathrm{kg}^{-1}\right)$ & $1.0 \pm 0.12 \mathrm{~b}$ & $3.3 \pm 0.45 \mathrm{a}$ & $0.8 \pm 0.07 \mathrm{~b}$ & $0.9 \pm 0.01 \mathrm{~b}$ \\
\hline Manganese $\left(\mathrm{mg} \mathrm{kg}^{-1}\right)$ & $26.4 \pm 3.45 b$ & $82.8 \pm 10.04 \mathrm{a}$ & $69.4 \pm 8.41 \mathrm{a}$ & $19.4 \pm 2.54 b$ \\
\hline
\end{tabular}

Means followed by the same letter are not significantly different by Tukey HSD test $(\alpha=0.05)$

new Phytophthora taxa present in Fagaceae forests in Austria, Italy and Portugal (Jung, Jung, Cacciola, et al., 2017b).

Tissue $\mathrm{N}$ concentration was noticeably higher in the phosphorous acid and metalaxyl treatments. However, plant $\mathrm{N}$ recovery was similar in all treatments. $\mathrm{N}$ is a limiting factor for plant growth, particularly in potted plants with reduced space for root expansion (Ferreira et al., 2020; Rodrigues et al., 2018), and can be taken up to luxury consumption levels when available in the soil
(Havlin et al., 2014). Thus, the lower $\mathrm{N}$ concentration in the control and K-silicate treatments was mainly the result of a dilution effect, which occurs due to the increase in plant biomass for the same amount of $\mathrm{N}$ available in the growing medium (Arrobas, Ferreira, et al., 2018b; Jarrel \& Beverly, 1981).

The higher tissue $\mathrm{P}$ concentration in the phosphorous acid treatment in comparison to the other treatments was due to the $\mathrm{P}$ content in the commercial product. The result was corroborated by the increase in soil extractable

Table 7 Selected soil properties (average \pm standard deviation) in the different treatments

\begin{tabular}{|c|c|c|c|c|}
\hline Soil properties & Control & Phosphorous acid & Metalaxyl & K-silicate \\
\hline${ }^{1}$ Organic $\mathrm{C}\left(\mathrm{g} \mathrm{kg}^{-1}\right)$ & $27.8 \pm 1.49 \mathrm{a}$ & $23.9 \pm 1.31 \mathrm{a}$ & $25.5 \pm 1.92 \mathrm{a}$ & $23.8 \pm 2.20 \mathrm{a}$ \\
\hline${ }^{2} \mathrm{pH}_{(\mathrm{H} 2 \mathrm{O})}$ & $5.6 \pm 0.08 \mathrm{~b}$ & $4.4 \pm 0.11 \mathrm{~d}$ & $4.9 \pm 0.05 \mathrm{c}$ & $6.3 \pm 0.20 \mathrm{a}$ \\
\hline${ }^{3}$ Extrac. $\mathrm{P}\left(\mathrm{mg} \mathrm{P}_{2} \mathrm{O}_{5} \mathrm{~kg}^{-1}\right)$ & $105.7 \pm 5.74 \mathrm{c}$ & $174.1 \pm 6.66 \mathrm{a}$ & $107.2 \pm 3.15 \mathrm{c}$ & $135.8 \pm 11.80 \mathrm{~b}$ \\
\hline${ }^{3}$ Extrac. $\mathrm{K}\left(\mathrm{mg} \mathrm{K}^{2} \mathrm{O} \mathrm{kg}^{-1}\right)$ & $308.3 \pm 17.56 \mathrm{~b}$ & $304.7 \pm 24.19 b$ & $314.0 \pm 21.07 \mathrm{~b}$ & $1953.3 \pm 80.83 \mathrm{a}$ \\
\hline${ }^{4}$ Exch. Ca $\left(\mathrm{cmol}_{\mathrm{c}} \mathrm{kg}^{-1}\right)$ & $2.8 \pm 0.14 \mathrm{~b}$ & $2.0 \pm 0.11 \mathrm{c}$ & $2.6 \pm 0.18 b$ & $3.2 \pm 0.15 \mathrm{a}$ \\
\hline${ }^{4}$ Exch. $\mathrm{Mg}\left(\mathrm{cmol}_{\mathrm{c}} \mathrm{kg}^{-1}\right)$ & $1.4 \pm 0.10 \mathrm{ab}$ & $0.9 \pm 0.18 \mathrm{c}$ & $1.1 \pm 0.13 \mathrm{bc}$ & $1.6 \pm 0.05 \mathrm{a}$ \\
\hline${ }^{4}$ Exch. K $\left(\mathrm{cmol}_{\mathrm{c}} \mathrm{kg}^{-1}\right)$ & $0.6 \pm 0.23 \mathrm{~b}$ & $0.6 \pm 0.15 b$ & $0.6 \pm 0.05 \mathrm{~b}$ & $3.8 \pm 0.04 \mathrm{a}$ \\
\hline${ }^{4}$ Exch. $\mathrm{Na}\left(\mathrm{cmol}_{\mathrm{c}} \mathrm{kg}{ }^{-1}\right)$ & $0.6 \pm 0.04 \mathrm{a}$ & $0.4 \pm 0.06 \mathrm{c}$ & $0.5 \pm 0.02 \mathrm{bc}$ & $0.5 \pm 0.06 \mathrm{ab}$ \\
\hline${ }^{5}$ Exch. acidity $\left(\mathrm{cmol}_{\mathrm{c}} \mathrm{kg}^{-1}\right)$ & $0.1 \pm 0.12 \mathrm{~b}$ & $0.8 \pm 0.23 \mathrm{a}$ & $0.2 \pm 0.06 \mathrm{~b}$ & $0.0 \pm 0.00 \mathrm{~b}$ \\
\hline${ }^{6} \mathrm{CEC}\left(\mathrm{cmol}_{\mathrm{c}} \mathrm{kg}^{-1}\right)$ & $5.6 \pm 0.35 \mathrm{~b}$ & $4.7 \pm 0.18 \mathrm{c}$ & $5.0 \pm 0.32 \mathrm{bc}$ & $9.2 \pm 0.11 \mathrm{a}$ \\
\hline${ }^{7}$ Extrac. B (mg kg ${ }^{-1}$ ) & $1.5 \pm 0.27 \mathrm{ab}$ & $1.2 \pm 0.10 \mathrm{~b}$ & $1.4 \pm 0.31 \mathrm{~b}$ & $2.1 \pm 0.13 \mathrm{a}$ \\
\hline${ }^{8}$ Extrac. $\mathrm{Cu}\left(\mathrm{mg} \mathrm{kg}^{-1}\right)$ & $2.2 \pm 0.60 \mathrm{a}$ & $1.7 \pm 0.09 \mathrm{a}$ & $1.7 \pm 0.39 \mathrm{a}$ & $1.9 \pm 0.03 \mathrm{a}$ \\
\hline${ }^{8}$ Extrac. Fe $\left(\mathrm{mg} \mathrm{kg}^{-1}\right)$ & $108.3 \pm 7.24 \mathrm{~b}$ & $121.3 \pm 19.61 \mathrm{ab}$ & $115.6 \pm 13.42 \mathrm{~b}$ & $163.0 \pm 23.07 \mathrm{a}$ \\
\hline${ }^{8}$ Extrac. $\mathrm{Zn}\left(\mathrm{mg} \mathrm{kg}^{-1}\right)$ & $1.3 \pm 0.13 b$ & $21.4 \pm 3.08 \mathrm{a}$ & $1.6 \pm 0.37 \mathrm{~b}$ & $1.3 \pm 0.05 \mathrm{~b}$ \\
\hline${ }^{8}$ Extrac. $\mathrm{Mn}\left(\mathrm{mg} \mathrm{kg}^{-1}\right)$ & $137.3 \pm 9.21 \mathrm{~b}$ & $235.6 \pm 18.23 \mathrm{a}$ & $151.3 \pm 13.37 \mathrm{~b}$ & $202.6 \pm 15.97 \mathrm{a}$ \\
\hline
\end{tabular}

${ }^{1}$ Walkley-Black; ${ }^{2}$ potentiometry; ${ }^{3}$ ammonium lactate; ${ }^{4}$ ammonium acetate, $\mathrm{pH} 7 ;{ }^{5}$ potassium chloride; ${ }^{6}$ cation exchange capacity (exch. Bases + exch. acidity); ${ }^{7}$ hot water, azomethine- $\mathrm{H} ;{ }^{7}$ ammonium acetate and EDTA

Means followed by the same letter are not significantly different by Tukey HSD test $(\alpha=0.05)$ 
P. After being added to the soil, the deprotonation of phosphorus acid makes phosphite available in the soil for plant uptake. Both phosphate and phosphite are acquired by plants via phosphate transporters (Jost et al., 2015). However, plants use phosphate and not phosphite in their metabolism. Oxidation of phosphite into phosphate, which could theoretically deliver usable P in the plant, is not documented in plant cells (du Jardin, 2012). However, in the soil, phosphite can undergo a gradual transformation, either by biological or non-biological oxidation. Soil microorganisms assimilate phosphite and release phosphate which can be taken up and used in plant nutrition. Phosphite oxidation to phosphate in soils lasts approximately 3-4 months (Gomez-Merino \& TrejoTelle, 2015), which is compatible with the use of $P$ from phosphorus acid applications in plant metabolism. Thus, it is possible that the plants took up phosphite and phosphate during the growing period. This defeats the thesis that there may have been $\mathrm{P}$ deficiency in the plants. The high $P$ values provided by tissue analysis are represented by all inorganic (phosphite and phosphate) and organic $P$ forms in the plant. It is well-known that when high levels of soluble phosphate are present in the soil, plant roots can accumulate $\mathrm{P}$ in high amounts as a reserve (Ferreira et al., 2018; Rodrigues et al., 2021), which allows the buffering of $\mathrm{P}$ levels in the shoots. Thus, these particularly high levels of $\mathrm{P}$ in plant tissues, particularly in the roots, can be $\mathrm{P}$ in phosphite but also in metabolizable forms, which reduces the likelihood of phosphite toxicity.

The concentration of $\mathrm{K}$ in plant tissues, particularly in the leaves, was especially high in the K-silicate treatment. The increase of $\mathrm{K}$ in the tissues was a direct response to the presence of the element in the commercial product, also corroborated by the high $\mathrm{K}$ values found in the soil. The type of soil used in this experiment tends to provide enough $\mathrm{K}$ for plant growth (Arrobas, Afonso, \& Rodrigues, 2018a; Arrobas et al., 2017) and it is unlikely that $\mathrm{K}$ per se played a relevant role in the performance of the plants or in their protection against Phytophthora.

$\mathrm{Ca}$ and $\mathrm{Mg}$ levels in plant tissues were also higher in the treatments producing less biomass. The result seems also to be a case of the dilution effect, although to a reduced extent in comparison with $\mathrm{N}$, perhaps because their concentrations in plant tissues tend to vary less than usually occurs with N (Bryson et al., 2014).

Regarding micronutrients, there was observed a tendency for $\mathrm{B}$ to be at higher levels in the treatments with less biomass production. It should be noted that these types of soils usually provide insufficient amounts of B for the normal growth of plants (Arrobas et al., 2017; Rodrigues et al., 2020). The difference between treatments seems to be, as in the case of $\mathrm{N}$, the result of a dilution effect. Regarding Fe, very high values were recorded in all treatments, especially in the roots. In pots, it is difficult to control water supply and aeration, which can reduce the redox potential in the soil, conditions which can lead to increased Fe bioavailability (Afonso et al., 2020). At excessive levels in the soil, $\mathrm{Fe}$ appeared concentrated in the roots as reported by Rodrigues et al. (2021). The levels of Zn were significantly higher in the phosphorous acid treatment, which were probably the result of the presence of the element in the commercial product. The levels of Mn were very high in the leaves and roots in all treatments. It is wellknown that chestnut accumulates high amounts of $\mathrm{Mn}$ in its tissues when grown in acidic soils where the element is found at high levels (Arrobas, Afonso, \& Rodrigues, 2018a; Arrobas et al., 2017). However, the values were particularly high in the phosphorus acid treatment due to the great reduction in soil $\mathrm{pH}$ caused (the original $\mathrm{pH}$ of the product is 0.3 ), which solubilized large quantities of $\mathrm{Mn}$. The commercial product also contains Mn, which also might have contributed to the increase of $\mathrm{Mn}$ in plant tissues. The metalaxyl treatment also caused a strong decrease in soil $\mathrm{pH}$, although less than that caused by phosphorous acid, and the Mn levels were much higher than in the control, but lower than in the phosphorus acid treatment. Thus, the marked decrease in plant growth in the phosphorous acid treatment followed by the metalaxyl treatment was probably due to Mn toxicity caused by the strong acidification of the soil. It should be noted that the higher limit of the sufficiency range for leaf $\mathrm{Mn}$ concentration is $2000 \mathrm{mg} \mathrm{kg}^{-1}$ (Arrobas, Afonso, \& Rodrigues, 2018a). In this study, the values exceeded $15,000 \mathrm{mg} \mathrm{kg}^{-1}$ in the phosphorous acid, and $8000 \mathrm{mg} \mathrm{kg}^{-1}$ in the metalaxyl, treatment.

\section{Conclusions}

The metalaxyl treatment provided great protection of plants against Phytophthora with no deaths recorded. However, under the conditions of this experiment, it resulted in a significant decrease in the plant growth performance, most likely due to the strong acidification of the soil which resulted in Mn toxicity. Phosphorous 
acid also greatly reduced plant death compared to the control, but plant growth was even more depressed than in the metalaxyl treatment as a result of a further lowering of the $\mathrm{pH}$ which caused an even more severe toxicity of Mn. Despite the effectiveness shown by these substances in reducing plant death caused by Phytophthora, it is also important to look at the concentration of the solutions, or the forms of the active ingredients, to reduce the risk of excessive soil acidification. This is particularly important for management strategies when foci of Phytophthora root rot suddenly appear, and it is necessary to limit the damage and prevent the natural spread of the inoculum. In the case of phosphorous acid, perhaps the application of their salts (phosphites) is a way of maintaining the positive results of plant protection while avoiding the problem of soil acidification. The use of K-silicate did not show such negative effects on the growth of the treated plants but gave less protection against Phytophthora in comparison to phosphorous acid and especially to metalaxyl. Phytophthora root rot management is most successful when active ingredients with different modes of action are integrated with a set of preventive and cultural practices over the long lifespan of chestnut trees.

Acknowledgments This research was funded by the Foundation for Science and Technology (FCT, Portugal) and FEDER under Programme PT2020 for financial support to CIMO (UIDB/00,690/2020). The research was integrated in the activities of the Operational Group EGIS - Estratégias de Gestão Integrada do Solo e da Água em Espécies Produtoras de Frutos Secos, and Operational Group Biochetnut IPM, funded by PT2020 and EAFRD (European Agricultural Fund for Rural Development).

\section{Compliance with ethical standards}

Ethical approval This article does not contain any studies with human participants or animals performed by any of the authors.

Informed consent Informed consent was not applicable to this article since no information regarding individual participants was included in the study.

Conflict of interest The authors declare no conflict of interest.

\section{References}

Afonso, S., Arrobas, M., \& Rodrigues, M. A. (2020). Soil and plant analyses to diagnose hop fields irregular growth. Journal of Soil Science and Plant Nutrition, 20, 1999-2013.
Akilli, S., Serçe, Ç. U., Katircioğlu, Y. Z., \& Maden, S. (2012). Involvement of Phytophthora spp. in chestnut decline in the Black Sea region of Turkey. Forest Pathology, 42, 377-386.

Akinsanmi, O. A., \& Drenth, A. (2013). Phosphite and metalaxyl rejuvenate macadamia trees in decline caused by Phytophthora cinnamomi. Crop Protection, 53, 29-23.

Arrobas, M., Afonso, S., Ferreira, I. Q., Moutinho-Pereira, J. M., Correia, C. M., \& Rodrigues, M. A. (2017). Liming and application of nitrogen, phosphorus, potassium and boron on a young plantation of chestnut. Turkish Journal of Agriculture and Forestry, 41, 441-451.

Arrobas, M., Afonso, S., \& Rodrigues, M. A. (2018a). Diagnosing the nutritional condition of chestnut groves by soil and leaf analyses. Scientia Horticulturae, 228, 113-121.

Arrobas, M., Ferreira, I. Q., Afonso, S., \& Rodrigues, M. A. (2018b). Sufficiency ranges and crop nutrient removals for peppermint (Mentha $\mathrm{x}$ piperita $\mathrm{L}$.) established from field and pot fertilizer experiments. Communications in Soil Science and Plant Analysis, 49(14), 1719-1730.

Balbino, L. R. (1968). La méthode Egner-Riehm et la détermination du phosfore et du potassium «assimilável» des sols du Portugal. II Col. Medit Cont. Fert. Plantas Cultivadas, pp 55-65.

Barrett, S. R., Shearer, B. L., \& Hardy, G. E. (2004). Phytotoxicity in relation to in planta concentration of the fungicide phosphite in nine Western Australian native species. Australasian Plant Pathology, 33, 521e528.

Bekker, T. F., Labuschagne, N., Aveling, T., Regnier, T., \& Kaiser, C. (2014). Effects of soil drenching of water-soluble potassium silicate on commercial avocado (Persea americana mill.) orchard trees infected with Phytophthora cinnamomi Rands on root density, canopy health, induction and concentration of phenolic compounds. South African Journal of Plant and Soil, 31, 101-107.

Biocca, M., Motta, E., Cacciola, S. O., \& Magnano Di San Lio, G. (1993). Identification of Phytophthora spp. associated with ink disease of chestnut in Central Italy. Proc. International Congress on Chestnut, Spoleto (Italy), pp. 527-532.

Bryson, G., Mills, H., Sasseville, D., Jones Jr., J. B., \& Barker, A. (2014). Plant analysis handbook III: A guide to sampling, preparation, analysis and interpretation for agronomic and horticultural crops. Micro-Macro Publishing.

Carneiro-Carvalho, A., Pereira, C., Marques, T., Martins, L., Anjos, R., Pinto, T., Lousada, J., \& Gomes-Laranjo, J. (2017). Potential of silicon fertilization in the resistance of chestnut plants to ink disease (Phytophthora cinnamomi). International Journal of Environment, Agriculture and Biotechnology, 2(5), 2740-2753.

Carneiro-Carvalho, A., Anjos, R., Aires, A., Marques, T., Pinto, T., \& Gomes-Laranjo, J. (2019). Ecophysiological study of the impact of $\mathrm{SiK} \circledast$ fertilization on Castanea sativa mill. Seedling tolerance to high temperature. Photosynthetica, 57(4), 1165-1175.

Carneiro-Carvalho, A., Anjos, R., Pinto, T., \& Gomes-Laranjo, J. (2020). Stress oxidative evaluation on SiK®-supplemented Castanea sativa mill. Plants Growing Under High Temperature. Journal of Soil Science and Plant Nutrition, 21, 415-425. https://doi.org/10.1007/s42729-020-00370-3.

Coelho, V. (2009). Efeito do fosfonato de potássio na protecção das raízes do castanheiro (Castanea sativa Mill.) contra 
Phytophthora cinnamomi. MSc Thesis in Agroecology. Instituto Politécnico Bragança. 97 p.

Cohen, Y., \& Coffey, M. D. (1986). Systemic fungicides and the control of oomycetes. Annual Review of Phytopathology, 24, 311-338.

Crandall, B. S., Gravatt, G. F., \& Ryan, M. M. (1945). Root disease of Castanea species and some coniferous and broadleaf nursery stocks, caused by Phytophthora cinnamomi. Phytopathology, 35, 162-180.

Crane, C. E., \& Shearer, B. L. (2014). Comparison of phosphite application methods for control of Phytophthora cinnamomi in threatened communities. Australasian Plant Pathology, 43, 143-149.

Darvas, J. M., Toerien, J. C., \& Milne, D. L. (1984). Control of avocado root rot by trunk injection with phosethyl-Al. Plant Disease, 68, 691-693.

Davidse, L. C. (1987). Biochemical aspects of phenylamide fungicides - Action and resistance. In H. Lyr (Ed.), Modern selective fungicides - Properties, applications, mechanisms of action. Longman Sci. and Tech. Co. and John Wiley \& Sons.

Dobrowolski, M. P., Shearer, B. L., Colquhoun, I. J., O’Brien, P. A., \& Hardy, G. E. S. (2008). Selection for decreased sensitivity to phosphite in Phytophthora cinnamomi with prolonged use of fungicide. Plant Pathology, 57, 928-936.

du Jardin, P. (2012). The science of plant biostimulants: A bibliographic analysis. Adhoc study report to the European Commission DG ENTR. http://ec.europa. eu/enterprise/sectors/chemicals/files/fertilizers/finalreport bio 2012en.Pdf.

Erwin, C. D., \& Ribeiro, K. O. (1996). Phytophthora - diseases worldwide. American Phytopathological Society.

FAOSTAT. (2020). Production: Crops. http://www.fao. org/faostat/en/\#data/QC. Accessed November 2020.

Fenn, M. E., \& Coffey, M. D. (1984). Studies on the in vitro and in vivo antifungal activity of Fosetyl-Al and phosphorus acid. Phytopathology, 74(5), 606-611.

Fernandes, C. T. (1979). Enfermedad de la tinta del castaño. Boletin de Sanidad Vegetal. Plagas, 5, 59-66.

Ferreira, I. Q., Rodrigues, M. A., Moutinho-Pereira, J. M., Correia, C., \& Arrobas, M. (2018). Olive tree response to applied phosphorus in field and pot experiments. Scientia Horticulturae. Scientia Horticulturae, 234, 236-244.

Ferreira, I. Q., Arrobas, M., Moutinho-Pereira, J. M., Correia, C. M., \& Rodrigues, M. A. (2020). The effect of nitrogen applications on the growth of young olive trees and nitrogen use efficiency. Turkish Journal of Agriculture and Forestry, 44, 278-289.

Gomez-Merino, F. C., \& Trejo-Telle, L. L. (2015). Biostimulant activity of phosphite in horticulture. Scientia Horticulturae, 196, 82-90.

González, M., Romero, M.-Á., Serrano, M.-S., \& Sánchez, M.-E. (2020). Fosetyl-aluminium injection controls root rot disease affecting Quercus suber in southern Spain. European Journal of Plant Pathology, 156(1), 101-109.

Gouveia, E. (1993). Doença da Tinta do Castanheiro. Avaliação da resistência à Phytophthora cinnamomi Rands. MSc Thesis, Proteção Integrada. Universidade Técnica de Lisboa, Instituto Superior de Agronomia, Lisboa, 135 p.

Gouveia, E. (2004). Métodos moleculares na identificação, caracterização e detecção de Phytophthora cambivora
(Petri) Buisman e Phytophthora cinnamomi Rands associadas com a doença da tinta do castanheiro. $\mathrm{PhD}$ Thesis, Ciências Agronómicas/Protecção de Plantas, UTAD. Vila Real, 163 p.

Gouveia, E., Coelho, V., Sousa, N., Coutinho, S., Nunes, L., \& Monteiro, M. L. (2009). Um método eficiente para a detecção de Phytophthora cinnamomi associada com a Doença da Tinta do Castanheiro na rizosfera de castanheiro (Castanea sativa Mill.). Revista de Ciências Agrárias, 32(1), 130-138.

Guest, D. I., \& Bompeix, G. (1990). The complex mode of action of phosphonates. Australasian Plant Pathology, 19, 113115 .

Guest, D., \& Grant, B. R. (1991). The complex action of phosphonates as antifungal agents. Biological Reviews, 66, 159-187.

Guest, D. I., Pegg, K. C., \& Whiley, A. W. (1995). Control of Phytophthora diseases of tree crops using trunk-injected phosphonates. Horticultural Reviews, 17, 299-330.

Hardham, A. R., \& Blakman, L. M. (2018). Phytophthora cinnamomi - pathogen profile update. Molecular Plant Pathology, 19(2), 260-285.

Havlin, J. L., Tisdale, S. L., Nelson, W. L., \& Beaton, J. D. (2014). Soil fertility and fertilizers, an introduction to nutrient management (8th ed.). Pearson.

Hibbett, D., Abarenkov, K., Kõljalg, U., Öpik, M., Chai, B., Cole, J., Wang, Q., Crous, P., Robert, V., Helgason, T., Herr, J., Kirk, P., Lueschow, S., O’Donnell, K., Nilsson, R., Oono, R., Schoch, C., Smyth, C., Walker, D., Porras-Alfaro, A., Taylor, J., \& Geiser, D. (2016). Sequence-based classification and identification of Fungi. Mycologia, 108(6), 1049-1068.

Hu, J., Hong, C., \& Strmoberg, E. L. (2010). Mefenoxam sensitivity in Phytophthora cinnamomi isolates. Plant Disease, 94, 39-44.

Jarrel, W. M., \& Beverly, R. B. (1981). The dilution effect in plant nutrition studies. Advances in Agronomy, 34, 197-224.

Jost, R., Pharmawati, M., Lapis-Gaza, H. R., Rossig, C., Berkowitz, O., Lambers, H., \& Finnegan, P. M. (2015). Differentiating phosphate-dependent and phosphateindependent systemic phosphate-starvation response networks in Arabidopsis thaliana through the application of phosphite. Journal of Experimental Botany, 66(9), 25012514.

Jung, T., Jung, M. H., Scanu, B., Seress, D., Kovács, G. M., Maia, C., Pérez-Sierra, A., Chang, T.-T., Chandelier, A., Heungens, K., Van Poucke, K., Abad-Campos, P., Léon, M., Cacciola, S. O., \& Bakonyi, J. (2017a). Six new Phytophthora species from ITS clade $7 \mathrm{a}$ including two sexually functional heterothallic hybrid species detected in natural ecosystems in Taiwan. Persoonia, 38(36), 100-135.

Jung, T., Jung, M. H., Cacciola, S. O., Cech, T., Bakonyi, J., Seress, D., Mosca, S., Schena, L., Seddaiu, S., Pane, A., Magnano, G., Maia, C., Cravador, A., Franceschini, A., \& Scanu, B. (2017b). Multiple new cryptic pathogenic Phytophthora species from Fagaceae forests in Austria, Italy and Portugal. IMA Fungus, 8(2), 219-244.

Kaiser, C., van der Merwe, R., Bekker, T. F., \& Labuschagne, N. (2005). In-vitro inhibition of mycelial growth of several phytopathogenic fungi, including Phytophthora cinnamomi by soluble silicon. South African Avocado Growers' Association Yearbook, 28, 70-74pp. 
Kim, S. G., Kim, K. W., Park, E. W., \& Choi, D. (2002). Siliconinduced cell wall fortification of rice leaves: A possible cellular mechanism of enhanced host resistance to blast. Phytopathology, 92, 1095-1103.

Liljeroth, E., Lankinen, A., Wiik, L., Burra, D. D., Alexandersson, E., \& Andreasson, E. (2016). Potassium phosphite combined with reduced doses of fungicides provides efficient protection against late blight in large-scale field trials. Crop Protection, $86,42-55$.

Lu, F., Zhao, J., Wu, J., Han, X., Wang, W., Liu, X., \& Meng, R. (2018). Monitoring of resistance of phytophthora infestans on potato to metalaxyl and the control efficacy of alternative fungicides. Scientia Agricultura Sinica, 51(14), 2700-2710.

Ma, J. F., \& Takahashi, E. (2002). Soil, fertilizer, and plant silicon research in Japan. Elsevier.

Martins, L., Castro, J., Macedo, W., Marques, C., \& Abreu, C. (2007). Assessment of the spread of chestnut ink disease using remote sensing and geostatistical methods. European Journal of Plant Pathology, 119, 159-164.

Masikane, S. L., Novela, P., Mohale, P., \& McLeod, A. (2020). Effect of phosphonate application timing and -strategy on phosphite fruit and root residues of avocado. Crop Protection, 128, 105008.

McDonald, A. E., Grant, R. R., \& Plaxton, W. C. (2001). Phosphite (phosphorous acid): Its relevance in the environment and agriculture and influence on plant phosphate starvation response. Journal of Plant Nutrition, 24, 1505-1519.

Nyoni, M., Lötze, E., Mazzola, M., Wessels, J. P. B., \& McLeod, A. (2019). Evaluating different approaches in the application of phosphonates for the control of apple root diseases. Plant Pathology, 48(5), 461-472.

Petri, L. (1917). Ricerche sulla morfologia e biologia della Blepharospora cambivora, parasitica del castagno (research on the morphology and biology of Blepharospora cambivora, parasitica from Chestnut): Atti Regia Accademia dei Lincei, 26, 297-299.

Pilbeam, R. A., Colquhoun, I. J., Shearer, B., \& Hardy, G. E. S. J. (2000). Phosphite concentration: Its effect on phytotoxicity symptoms and colonisation by Phytophthora cinnamomi in three understorey species of Eucalyptus marginata forest. Australasian Plant Pathology, 29, 86-95.

Ramírez-Gil, J. G., \& Morales-Osorio, J. G. (2020). Integrated proposal for management of root rot caused by Phytophthora cinnamomi in avocado cv. Hass crops. Crop Protection, 137, 105271.

Rodrigues, M. A., Ferreira, I. Q., Afonso, S., \& Arrobas, M. (2018). Sufficiency ranges and nutrient removals in lemon balm based on crop response to applied nitrogen, phosphorus, potassium and boron. Journal of Plant Nutrition, 41(8), 996-1008.

Rodrigues, M. A., Grade, V., Barroso, V., Pereira, A., Cassol, L. C., \& Arrobas, M. (2019). Chestnut response to organo- mineral and controlled-release fertilizers in rainfed growing conditions. Journal of Soil Science and Plant Nutrition, 20, 380-391.

Rodrigues, M. A., Raimundo, S., Pereira, A., \& Arrobas, M. (2020). Large chestnut trees (Castanea sativa) respond poorly to liming and fertilizer application. Journal of Soil Science and Plant Nutrition, 20, 1261-1270.

Rodrigues, M. A., Piroli, L. B., Forcelini, D., Raimundo, S., Domingues, L. S., Cassol, L. C., Correia, C. M., \& Arrobas, M. (2021). Use of commercial mycorrhizal fungi in stress-free growing conditions of potted olive cuttings. Scientia Horticulturae, 275, 109712.

Savvas, D., \& Ntatsi, G. (2015). Biostimulant activity of silicon in horticulture. Scientia Horticulturae, 196, 66-81.

Schwinn, F. J., Staub, T., \& Urech, P. A. (1977). A new fungicide against diseases caused by oomycetes. Mededelingen van de Faculteit Landbouwwetenschappen, Rijksuniversiteit Gent, 42, 1181-1188.

Sousa, A., AbdElgawad, H., Asard, H., Pinto, A., Soares, C., Branco-Neves, S., Braga, T., Azenha, M., Selim, S., Al Jaouni, S., Fidalgo, F., \& Teixeira, J. (2017). Metalaxyl effects on antioxidant defenses in leaves and roots of Solanum nigrum L. Frontiers in Plant Science, 8, 1967.

Stein, J. M., \& Kirk, W. (2002). Containment of existing potato late blight (Phytophthora infestans) foliar epidemics with fungicides. Crop Protection, 21, 575-582.

Temminghoff, E. E. J. M., \& Houba, V. G. (2004). Plant analysis procedures (2nd ed.). Klwuwer Academic Publishers.

Türkölmez, S., \& Derviş, S. (2017). Activity of metalaxyl-M+ mancozeb, fosetyl-Al, and phosphorous acid against Phytophthora crown and root rot of apricot and cherry caused by Phytophthora palmivora. Plant Protection Science, 53, 216-225.

Urech, P. A., Schwinn, F. J., \& Staub, T. (1977). CGA 48988, a novel fungicide for the control of the late blight, downy mildews and related soil-borne diseases. Proc. $9^{\text {th }}$ British Crop Protection Conference, 2, 623-631.

Van Reeuwijk, L. P. (2002). Procedures for soil analysis (6th ed., technical paper 9). ISRIC, FAO.

Vannini, A., \& Vettraino, A. M. (2001). Ink disease in chestnuts: Impact on the European chestnut. Forest Snow and Landscape Research, 76(3), 345-350.

Vettraino, A. M., Morel, O., Perlerou, C., Robin, C., Diamandis, S., \& Vannini, A. (2005). Occurrence and distribution of Phytophthora species in European chestnut stands, and their association with ink disease and crown decline. European Journal of Plant Pathology, 111, 169-180.

White, T. J., Bruns, T., Lee, S., \& Taylor, J. (1990). Amplification and direct sequencing of fungal ribosomal RNA genes for phylogenetics. In M. Innis, D. Gelfand, J. Shinsky, \& T. J. White (Eds.), PCR protocols: A guide to methods and applications (pp. 315-322). Academic Press. 